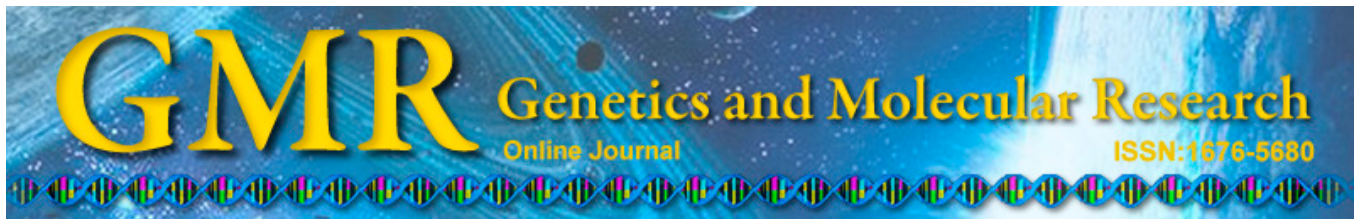

\title{
Critical electrolyte concentration of silk gland chromatin of the sugarcane borer Diatraea saccharalis, induced using agrochemicals
}

\author{
S.A. Santos, F. Fermino, B.M.T. Moreira, K.F. Araujo, J.R.P. Falco and \\ M.C.C. Ruvolo-Takasusuki \\ Departamento de Biotecnologia, Genética e Biologia Celular, \\ Universidade Estadual de Maringá, Maringá, PR, Brasil \\ Corresponding author: M.C.C. Ruvolo-Takasusuki \\ E-mail: mccrtakasusuki@uem.br
}

Genet. Mol. Res. 13 (3): 7958-7964 (2014)

Received August 15, 2013

Accepted January 10, 2014

Published September 29, 2014

DOI http://dx.doi.org/10.4238/2014.September.29.9

\begin{abstract}
The sugarcane borer Diatraea saccharalis is widely known as the main pest of sugarcane crop, causing increased damage to the entire fields. Measures to control this pest involve the use of chemicals and biological control with Cotesia flavipes wasps. In this study, we evaluated the insecticides fipronil (Frontline; 0.0025\%), malathion (Malatol Bio Carb; 0.4\%), cipermetrina (Galgotrin; 10\%), and neem oil (Natuneem; 100\%) and the herbicide nicosulfuron (Sanson $40 \mathrm{SC} ; 100 \%$ ) in the posterior region silk glands of 3rd- and 5th-instar $D$. saccharalis by studying the variation in the critical electrolyte concentration (CEC). Observations of 3rd-instar larvae indicated that malathion, cipermetrina, and neem oil induced increased chromatin condensation that may consequently disable genes. Tests with fipronil showed no alteration in chromatin condensation. With the use of nicosulfuron, there was chromatin and probable gene decompaction. In the 5th-instar larvae, the larval CEC values indicated that malathion and neem oil induced increased chromatin condensation. The CEC values for 5th-instar larvae using cipermetrina, fipronil, and nicosulfuron
\end{abstract}


indicated chromatin unpacking. These observations led us to conclude that the quantity of the pesticide does not affect the mortality of these pests, can change the conformation of complexes of DNA, RNA, and protein from the posterior region of silk gland cells of D. saccharalis, activating or repressing the expression of genes related to the defense mechanism of the insect and contributing to the selection and survival of resistant individuals.

Key words: Herbicide; Organophosphate; Pyrethroid; Phenyl pyrazole; Critical electrolyte concentration

\section{INTRODUCTION}

In the larval stage, the insect has a pair of silk glands that are responsible for the production of silk, which is fully developed in the last instar of larval development (Victoriano and Gregório, 2002; Victoriano et al., 2007).

Diatraea saccharalis, sugarcane borer, causes direct damage by drilling holes, leading to weight loss and causing the death of buds and gaps in sugarcane plantations (Botelho, 1992). When the insect is in the plant, it cuts the stem in circular galleries, causing the toppling of the cane by the wind and killing the new canes by drying pointers, which is known as dead heart. Moreover, indirect damage occurs due to the holes that are opened by the larvae, which allow the entrance of fungi and leaves the inside of the internodes with a red tint, decreasing the manufacturing yield by the inversion of sucrose, decreasing the purity of the juice, and causing contamination problems in the process of alcoholic fermentation by decreasing the production of sugar and alcohol (Botelho, 1992; Heideman et al., 2010).

Sugarcane borer also attacks other economically important crops such as Oryza sativa (Ferreira et al., 2004), Zea mays, and Sorghum bicolor (Boiça Junior and Lara, 1993).

The biological control of the sugarcane borer in Brazil is performed with the larval parasitoid Cotesia flavipes (Alleyne et al., 2001; Mahmoud et al., 2011). Other ways to combat these insects have also been studied and include using some kinds of fungi such as Metarhizium anisopliae (Acevedo et al., 2007), microorganisms such as Bacillus thuringiensis (Rosas-García, 2006; Wu et al., 2009; Huang et al., 2012), genetically modified plants (Huang et al., 2007), and agrochemicals (Stefanidou et al., 1996; Rodriguez et al., 2001).

Among the insecticides that are commonly used to control insects, organophosphates and pyrethroids stand out. They act by damaging the central nervous system of the target, leading to death (Sackmann et al., 2001). Tavares et al. (2010) used natuneem to control the outbreak of eggs of D. saccharalis and Spodoptera frugiperda.

Herbicides such as paraquat are also used in sugarcane fields to combat weeds and come in contact with pest insects, which may result in the activation of defense genes and stress responses (Hasunuma et al., 2011).

The exposure of insects to different agrochemicals on fields can lead to resistance (Denholm and Elliot, 1995), which can directly affect their gene expression and DNA. One way to investigate the integrity of the chromatin of insect cells that were induced by external agents is through the technique of critical electrolyte concentration (CEC). The CEC for nucleic acids in nucleoprotein complexes has been defined as the inorganic ion concentration at 
which the metachromasia due to nucleic acid toluidine blue staining (violet color) is abolished, and a green color appears (Vidal and Mello, 1989; Falco and Mello, 1999; Falco et al., 1999). The CEC of different DNA-protein complexes occurs at different $\mathrm{Mg}^{2+}$ concentrations (Vidal and Mello, 1989; Falco and Mello, 1999; Falco et al., 1999).

RNA analysis with the CEC method was based on the principle that the abolishment of DNA metachromasia occurs earlier than that of RNA (Mello et al., 1993).

This study aimed to observe the variability in the concentration of $\mathrm{Mg}^{2+}$ in which metachromasia was completely abolished (CEC) in the posterior region silk glands of $D$. saccharalis. These results may reflect differences at the level of nucleoprotein complexes that the stress induced through contact with agrochemicals.

\section{MATERIAL AND METHODS}

\section{Biological material}

The D. saccharalis larvae used in this study were obtained from the Department of Biotechnology, Genetics and Cell Biology (DBC), Universidade Estadual de Maringá, PR. They were kept in glass tubes containing an artificial diet that was developed by Hensley and Hammond (1968), with modifications. The rearing containers were placed in a biochemical oxygen demand chamber maintained under controlled temperature condition of $25^{\circ} \pm 1{ }^{\circ} \mathrm{C}, 70$ $\pm 10 \%$ relative humidity, and a photoperiod of $12 \mathrm{~h}$. Under the described conditions, the full life cycle of $D$. saccharalis was maintained, providing eggs, larvae, pupae, and adults. The adults remained in mating chambers that were built with polyvinyl chloride pipes that were 10 $\mathrm{cm}$ in diameter $\mathrm{x} 25 \mathrm{~cm}$ in height and internally coated with paper. After egg laying by the females, the eggs were collected, washed in appropriate solutions for sterilization, and analyzed in vivo with the aid of a stereoscopic microscope.

\section{Bioassays with agrochemicals}

Filter papers were placed on Petri dishes $(120 \times 20 \mathrm{~mm})$, and $1 \mathrm{~mL}$ solution containing each agrochemical was added (Table 1).

\begin{tabular}{lc} 
Table 1. Agrochemical concentrations used. & \\
\hline Agrochemical & Concentration (\%) \\
\hline Malathion (Malatol Bio Carb) & 0.4 \\
Neem oil (Natuneem) & 100.0 \\
Cipermetrina (Galgotrin) & 10.0 \\
Nicosulfuron (Sanson 40 SC) & 100.0 \\
Fipronil (Frontline) & 0.0025 \\
\hline
\end{tabular}

These filter papers were used for experiments with 3rd- and 5th-instar larvae. The concentration of each of the agrochemicals that was used was based on the application field, administering a sublethal dose for the insect. Previous tests were conducted to define optimal concentrations for use in the experiment (Santos SA, Fermino F, Moreira BMT, Araujo KF, et al., unpublished data). For the control group, $1 \mathrm{~mL}$ distilled water was placed 
on the filter paper. Then, 20 larvae were placed on each plate containing artificial diet and were kept $24 \mathrm{~h}$ under controlled temperature at $25^{\circ} \pm 1{ }^{\circ} \mathrm{C}, 70 \pm 10 \%$ relative humidity, and a photoperiod of $12 \mathrm{~h}$. After this time, the larvae were sacrificed and dissected, and their silk glands were removed and used in the preparation of the slides.

\section{Preparation of slides}

After dissecting the posterior region silk glands, they were placed on slides with $45 \%$ acetic acid and crushed to separate the cellular material. Afterwards, the slides were immersed in liquid nitrogen and subsequently fixed for $2 \mathrm{~min}$ in ethanol:acetic acid $(3: 1, \mathrm{v} / \mathrm{v})$ followed by $10 \mathrm{~min}$ in a solution of $70 \%$ ethanol.

\section{CEC test}

The cells were stained for $20 \mathrm{~min}$ in a solution of Mcllvaine buffer, $\mathrm{pH}$ 4.0, containing $0.025 \%$ toluidine blue (Merck, Germany) in the absence or presence of various concentrations $(0.02,0.05,0.08,0.10,0.12,0.15,0.20$, and $0.30 \mathrm{M})$ of $\mathrm{MgCl}_{2}$ (Merck). To verify the presence of RNA, after the previous step of staining with toluidine blue, the slides were placed in a solution of $0.05 \mathrm{M} \mathrm{MgCl}_{2}$ (Merck) and withdrawn after 5, 10, and 15 min (Mello et al., 1993, 1999). Then, the slides were washed in distilled water for $5 \mathrm{~s}$, dried at room temperature, kept for $15 \mathrm{~min}$ in xylene, and mounted with Entellan (Merck). For the analysis of the slides, a Zeiss Axioskop 40 microscope was used along with the Axion Vision 4.6 software. The nuclei of the cells of the posterior region silk glands that were stained violet were the controls and the green color correspond to the CEC point.

\section{RESULTS}

In 3rd-instar larvae, malathion, cipermetrina, and neem oil increased chromatin condensation, which consequently may disable genes (Table 2). The DNA-protein complexes of posterior region silk glands of the 3rd-instar larvae that contacted fipronil were not different from those of the control treatment (Table 2). Nicosulfuron resulted in a small decrease in the $\mathrm{CEC}$ value, indicating that there was little unpacking of chromatin compared to the control, and we may assume that genes were active (Table 2).

The CEC values that were found in the posterior region silk glands of $D$. saccharalis in the 5th instar showed chromatin condensation with the use of malathion and neem oil, and the CEC values in the 3rd instar also pointed toward this observation (Table 2). Fifth-instar larvae that were treated with cipermetrina and fipronil showed little difference compared to the control samples, indicating that these insecticides induced no chromatin condensation in the 5th instar. This result was unlike the results that were observed in the 3rd instar, in which cipermetrina induced chromatin condensation. In the 5th instar, the CEC point for the nicosulfuron suggested that the herbicide induced chromatin relaxation.

The analysis of the cells using the modified CEC technique to check the RNA showed similar results for all agrochemicals, showing the abolition of metachromasia of DNA in 10 min and cytoplasm with an intense RNA presence mainly in the 5th instar when the peak of silk production occurs. 
Table 2. Critical electrolyte concentration (CEC) values for the chromatin in silk gland cells of 3rd- and 5thinstar Diatraea saccharalis.

\begin{tabular}{lcc}
\hline Agrochemical & CEC 3rd instar (M) & CEC 5th instar (M) \\
\hline Control & 0.12 & $0.08-0.10$ \\
Malathion (Malatol Bio Carb) & $0.15-0.20$ & $0.15-0.20$ \\
Neem oil (Natuneem) & 0.15 & 0.15 \\
Cipermetrina (Galgotrin) & 0.15 & 0.08 \\
Nicosulfuron (Sanson 40 SC) & $0.05-0.08$ & $0.05-0.08$ \\
Fipronil (Frontline) & 0.12 & 0.08 \\
\hline
\end{tabular}

\section{DISCUSSION}

Magaña et al. (2008) found that a single-point mutation in acetylcholinesterase in Ceratitis capitata is associated with malathion resistance. Bioinsecticides, such as neem oil, work only on the 1st-instar larvae and reduce the hatching of $D$. saccharalis eggs (Tavares et al., 2010). Batabyal et al. (2009) observed that this bioinsecticide is effective in controlling the insect Culex quinquefasciatus.

In studies using butane-fipronil on the 4th instar of Plutella xylostella larvae, Liu et al. (2009) observed that the larvae resistance increased 83.80 times after 10 generations compared to the control larvae.

The use of insecticide is often integrated with biological control of pests such as the sugarcane borer. This helps to reduce infestation because, when values exceed $3 \%$ of the plantation area, biological control using C. flavipes is not enough (Alleyne et al., 2001; Mahmoud et al., 2011). Furthermore, in many cases, it is necessary to mix insecticides to decrease the resistance that is acquired by the insects. A mixture of chemicals was used to treat Spodoptera litura, and the combination of fipronil and cipermetrina efficiently controlled the insect (Ahmad et al., 2009).

Sugarcane requires the use of herbicides for weed control. Contact with this type of product could stimulate some kind of insect response that elicits a change in the CEC level. Nicosulfuron induced chromatin relaxation in 2 instars, allowing gene activation.

Arthropods, such as Edaphic collembola, were also studied to verify the effect of contact with nicosulfuron (Bretaud et al., 2000; Lins et al., 2007); arthropod populations declined and there were changes in the activity and molecular forms of acetylcholinesterase.

Fermino et al. (2010) also used CECs to study the nuclear activity of Malpighian tubules of $D$. saccharalis, which are divided into 3 regions: proximal, middle, and distal; differences in the CECs between the regions were identified. The 5th instar has chromatin that is more decondensed than in the fourth instar. The distal tubule region was the most decondensed region of the Malpighian tubules. Our data show that the Malpighian tubules had an elevated genetic activity in the pre-metamorphosis period.

Differences among the 3rd-instar larvae may occur because during the 5th instar of larval development, the silk gland is highly active synthetizing silk (Victoriano and Gregório, 2002; Victoriano et al., 2007) to weave a cocoon for pupation.

Another important factor that can be triggered by stress in the insect contact with agrochemicals includes heat shock proteins. These proteins play an important role in protein interactions such as protein folding, assisting in establishing the proper conformation of proteins, and preventing unwanted protein aggregation (Qin et al., 2003; Sonoda et al., 2006; Sharma et al., 2012). 
The effect of fixation in acetic acid and ethanol on the results reported herein may be considered because the partial extraction of the core histones of the cells was reported after the action of fixatives, especially after long periods (Mello, 1979). However, it is assumed that most of the histones are not extracted during the short period of fixation that was used in this experiment because the recovery of nuclear metachromasia after reaching the CEC was observed in this and other studies (Mello and Falco, 1996; Monteiro and Mello, 1998).

The analysis of the posterior region silk glands of $D$. saccharalis allowed us to verify differences in CEC points relative to the investigated stages according to the agrochemical that was used. This analysis revealed that, depending on the concentration of the agrochemical, which is often a sublethal amount, changes occur in the chromatin, activating or repressing genes that are likely linked to this defense mechanism and may contribute to the selection and survival of resistant individuals.

\section{ACKNOWLEDGMENTS}

We thank Valmir Peron for his dedicated technical assistance and for raising the insects.

\section{REFERENCES}

Acevedo JP, Samuels RI, Machado IR and Dolinski C (2007). Interactions between isolates of the entomopathogenic fungus Metarhizium anisopliae and the entomopathogenic nematode Heterorhabditis bacteriophora JPM4 during infection of the sugar cane borer Diatraea saccharalis (Lepidoptera: Pyralidae). J. Invertebr. Pathol. 96: 187-192.

Ahmad M, Saleem MA and Sayyed AH (2009). Efficacy of insecticide mixtures against pyrethroid- and organophosphateresistant populations of Spodoptera litura (Lepidoptera: Noctuidae). Pest Manag. Sci. 65: 266-274.

Alleyne M, Wiedenmann RN and Diaz RR (2001). Quantification and development of teratocytes in novel-association host-parasitoid combinations. J. Insect Physiol. 47: 1419-1427.

Batabyal L, Sharma P, Mohan L, Maurya P, et al. (2009). Relative toxicity of neem fruit, bitter gourd, and castor seed extracts against the larvae of filaria vector, Culex quinquefasciatus (Say). Parasitol. Res. 105: 1205-1210.

Boiça Júnior AL and Lara FM (1993). Resistência de genótipos de sorgo ao ataque de Diatraea saccharalis (Fabr.) (Lepidoptera: Pyralidae). An. Soc. Entomol. Bras. 22: 245-252.

Botelho PSM (1992). Quinze anos de controle biológico da Diatraea saccharalis utilizando parasitoides. Pesq. Agropec. Bras. 27: 255-262.

Bretaud S, Toutant JP and Saglio P (2000). Effects of carbofuran, diuron, and nicosulfuron on acetylcholinesterase activity in goldfish (Carassius auratus). Ecotoxicol. Environ. Saf. 47: 117-124.

Denholm I and Elliot M (1995). Roman Mieczyslaw Sawicki. Biogr. Mem. Fell. R. Soc. 41: 395-418.

Falco JRP and Mello MLS (1999). Critical electrolyte concentration of spermatozoal chromatin containing histone H1 variants. Genet. Mol. Biol. 22: 197-200.

Falco JRP, Mello MLS, Maria SS and Grazziotin NA (1999). Critical electrolyte concentration of chicken erythrocyte chromatin. Acta Histochem. Cytochem. 32: 73-76.

Fermino F, Conte H and Falco JR (2010). Analysis of nucleus activity in malpighian tubules of Diatraea saccharalis (Fabricius) (Lepidoptera: Crambidae) larvae by critical electrolyte concentration. Neotrop. Entomol. 39: 568-571.

Ferreira E, Barrigossi JAF and Santos AB (2004). Perdas de produção pela broca-do-colmo (Diatraea saccharalis Fabr. 1794) (Lepidoptera: Pyralidae) em genótipos de arroz de Terras Altas. Pesq. Agrop. Trop. 34: 99-103.

Hasunuma K, Yoshida Y, Haque ME, Wang NY, et al. (2011). Global warming, plant paraquat resistance, and light signal transduction through nucleoside diphosphate kinase as a paradigm for increasing food supply. Naunyn Schmiedebergs Arch. Pharmacol. 384: 391-395.

Heideman C, Munhoz RE, Pattaro Junior JR and Fernandez MA (2010). Genetic diversity analysis with RAPD linked to sex identification in the sugar cane borer Diatraea saccharalis. Genet. Mol. Res. 9: 2343-2348.

Hensley SD and Hammond AM (1968). Laboratory techniques for rearing the sugarcane borer on an artificial diet. J. Econ. Entomol. 61: 1742-1743.

Huang FN, Leonard BR and Andow DA (2007). F2 screen for resistance to a Bacillus thuringiensis-maize hybrid in the sugarcane borer (Lepidoptera: Crambidae). Bull. Entomol. Res. 97: 437-444. 
Huang FN, Ghimire MN, Leonard BR, Daves C, et al. (2012). Extended monitoring of resistance to Bacillus thuringiensis Cry1 Ab maize in Diatraea saccharalis (Lepidoptera: Crambidae). GM Crops Food 3: 245-254.

Lins VS, Santos HR and Goncalves MC (2007). The effect of the glyphosate, 2,4-D, atrazine e nicosulfuron herbicides upon the Edaphic collembola (Arthropoda: Ellipura) in a no tillage system. Neotrop. Entomol. 36: 261-267.

Liu S, Niu H, Xiao T, Xue C, et al. (2009). Does phenoloxidase contributed to the resistance? Selection with butanefipronil enhanced its activities from diamondback moths. Open Biochem. J. 3: 9-13.

Magaña C, Hernández-Crespo P, Brun-Barale A, Couso-Ferrer F, et al. (2008). Mechanisms of resistance to malathion in the medfly Ceratitis capitata. Insect Biochem. Mol. Biol. 38: 756-762.

Mahmoud AM, De Luna-Santillana EJ and Rodriguez-Perez MA (2011). Parasitism by the endoparasitoid, Cotesia flavipes induces cellular immunosuppression and enhances susceptibility of the sugar cane borer, Diatraea saccharalis to Bacillus thuringiensis. J. Insect. Sci. 11: 119.

Mello MLS (1979). Patterns of lability towards acid hydrolysis in heterochromatins and euchromatins of Triatoma infestans Klug. Cell. Mol. Biol. 24: 1-16.

Mello MLS and Falco JRP (1996). Critical electrolyte concentration of DNA-protein complexes in spermatozoal and somatic cell nuclei of the honey bee, Apis mellifera. Insect Biochem. Mol. Biol. 26: 793-795.

Mello MLS, Vidal BC, Dantas MM and Monteiro AL (1993). Discrimination of the nucleolus by a critical electrolyte concentration method. Acta Histochem. Cytochem. 26: 1-3.

Mello MLS, Barbisan LF, Russo J and Vidal BD (1999). RNA relocation at mitosis in transformed and tumorigenic human breast epithelial cells. Cell Biol. Int. 23: 125-128.

Monteiro ALP and Mello MLS (1998). Critical electrolyte concentration of chromatin in polytene chromosomes of Trichosia pubescens (Diptera, Sciaridae). Genet. Mol. Biol. 21: 185-190.

Qin W, Tyshenko MG, Wu BS, Walker VK, et al. (2003). Cloning and characterization of a member of the Hsp70 gene family from Locusta migratoria, a highly thermotolerant insect. Cell Stress Chaperones 8: 144-152.

Rodriguez LM, Reagan TE and Ottea JA (2001). Susceptibility of Diatraea saccharalis (Lepidoptera: Crambidae) to tebufenozide. J. Econ. Entomol. 94: 1464-1470.

Rosas-García NM (2006). Laboratory and field tests of spray-dried and granular formulations of a Bacillus thuringiensis strain with insecticidal activity against the sugarcane borer. Pest Manag. Sci. 62: 855-861.

Sackmann P, Rabinovich M and Corley JC (2001). Successful removal of German yellowjackets (Hymenoptera: Vespidae) by toxic baiting. J. Econ. Entomol. 94: 811-816.

Sharma A, Mishra M, Shukla AK, Kumar R, et al. (2012). Organochlorine pesticide, endosulfan induced cellular and organismal response in Drosophila melanogaster. J. Hazard. Mater. 221-222: 275-287.

Sonoda S, Ashfaq M and Tsumuki H (2006). Cloning and nucleotide sequencing of three heat shock protein genes (hsp90, hsc70, and hsp19.5) from the diamondback moth, Plutella xylostella (L.) and their expression in relation to developmental stage and temperature. Arch. Insect. Biochem. Physiol. 62: 80-90.

Stefanidou M, Koutselinis A, Pappas F and Methenitou G (1996). Bee head acetylcholinesterase as an indicator of exposure to organophosphate and carbamate insecticides. Vet. Hum. Toxicol. 38: 420-422.

Tavares WS, Cruz I, Fonseca FG, Gouveia NL, et al. (2010). Deleterious activity of natural products on postures of Spodoptera frugiperda (Lepidoptera: Noctuidae) and Diatraea saccharalis (Lepidoptera: Pyralidae). Z. Naturforsch. C 65: 412-418.

Victoriano E and Gregorio EA (2002). Ultrastructure of the excretory duct in the silk gland of the sugarcane borer Diatraea saccharalis (Lepidoptera: Pyralidae). Arthropod. Struct. Dev. 31: 15-21.

Victoriano E, Pinheiro DO and Gregorio EA (2007). Histochemical and ultrastructural evidence of lipid secretion by the silk gland of the sugarcane borer Diatraea saccharalis (Fabricius) (Lepidoptera: Crambidae). Neotrop. Entomol. 36: 707-711.

Vidal BC and Mello MLS (1989). Critical electrolyte concentration of DNA and nucleoprotein complexes in vitro. Acta Histochem. Cytochem. 22: 471-478.

Wu X, Rogers LB, Zhu YC, Abel CA, et al. (2009). Susceptibility of CrylAb-resistant and -susceptible sugarcane borer (Lepidoptera: Crambidae) to four Bacillus thuringiensis toxins. J. Invertebr. Pathol. 100: 29-34. 